\title{
Uji Diagnostik C-Reactive Protein, Leukosit, Nilai Total Neutrofil dan Suhu pada Anak Demam dengan Penyebah yang Tidak Diketahui
}

\author{
I Made Gede Dwi Lingga Utama \\ Bagian Ilmu Kesehatan Anak, Fakultas Kedokteran Universitas Udayana, RSUP Sanglah, Denpasar
}

Latar belakang. Demam tanpa penyebab yang jelas cukup sering kita jumpai dalam praktek sehari-hari. Penentuan penyebab pasti dengan biakan memerlukan waktu yang lama. Di lain pihak kita harus menentukan sesegera mungkin apakah demam ini disebabkan oleh infeksi bakteri atau tidak sehingga dapat segera mengambil keputusan pemberian antibiotik

Tujuan. Mencari pemeriksaan sederhana dan cepat untuk dapat dipakai sebagai pegangan menentukan infeksi bakteri.

Metode. Penelitian uji diagnostik dilakukan di Rumah Sakit Umum Pusat Nasional Cipto Mangunkusumo Jakarta dengan mengambil data secara retrospektif dari catatan medis tahun 2006 sampai dengan tahun 2008 (bulan Oktober). Data ditabulasi dicari nilai sensitivitas, spesifisitas, nilai duga positif, nilai duga negatif, rasio kemungkinan positif, rasio kemungkinan negatif dari CRP(C reactive protein), ANC (absolute neutrophil count = nilai neutrofil total), dan suhu, baik variabel tunggal maupun kombinasi dengan menggunakan baku emas biakan darah.

Hasil. Jumlah kasus demam yang tidak diketahui penyebabnya didapatkan 138 dengan 39 (28,3\%) kasus yang memiliki data lengkap. Biakan positif didapatkan pada 26 kasus (prevalensi 66,6\%). Umur ratarata subjek 3,5 tahun (umur termuda 2 bulan dan tertua 13 tahun), dan rerata suhu $38,8^{\circ} \mathrm{C}$. Sensitivitas pemeriksaan CRP, leukosit, ANC dan suhu didapatkan antara 42\% sampai 65\%. Spesifisitas didapatkan antara 46\% sampai dengan 54\%. Sensitivitas pemeriksaan kombinasi 15,4\%. Spesifisitas pemeriksaan kombinasi antara $70 \%$ sampai $85 \%$.

Kesimpulan. Nilai CRP, leukosit, ANC dan suhu tidak bisa dipakai sebagai prediktor infeksi bakteri pada anak dengan demam yang tidak diketahui penyebabnya. Sari Pediatri 2012;13(6):412-9.

Kata kunci: CRP, ANC, leukosit, suhu, demam tidak diketahui penyebabnya

\footnotetext{
Alamat korespondensi:

Dr. I Made Gede Dwi Lingga Utama, Sp.A. Divisi Infeksi dan Penyakit Tropis. Bagian/SMF Ilmu Kesehatan Anak FK Unud/RSUP Sanglah Denpasar. Jl. P. Nias Denpasar. Telp. (0361) 244038. E-mail: dwi lingga09@yahoo.com
}

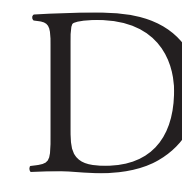
emam tanpa penyebab yang jelas masih sering kita hadapi dalam praktek seharihari. Sering kali kita harus memasukkan pasien tersebut ke rumah sakit untuk tujuan evaluasi mencari penyebab. Penyebab demam 
yang berkepanjangan memang tidak selalu mudah kita tegakkan. Bahkan dalam praktek sehari-hari kita terlalu sering memberikan antibiotik untuk pasien tersebut walaupun kita belum pasti tahu penyebabnya. Dari penelitian-penelitian ditemukan paling banyak penyebab demam yang tidak diketahui adalah infeksi bakteri. $^{1}$

Dengan hanya melihat gejala klinis saja sulit untuk menentukan fokus infeksi pada kasus tersebut, sehingga sering kita sebagai praktisi mengambil jalan pintas memberikan antibiotik awal untuk tujuan yang tidak tepat. Penelusuran penyebab memang sangat penting untuk segera dilakukan. Akan tetapi keadaan di lapangan tidak selalu mudah oleh karena keterbatasan sarana, maupun kemampuan kita dalam menegakkan diagnosis yang tepat. Untuk kasus demam dengan gejala toksik sering kita memasukkan pasien ke rumah sakit dan langsung memberikan antibiotik secara empiris, akan tetapi dalam situasi rawat jalanpun sering terjadi pemberian antibiotik padahal kita belum yakin penyebab demamnya oleh karena infeksi bakteri.

Idealnya dalam menentukan tata laksana penyebab demam tersebut memang harus dicari, namun karena kesulitan tadi kita tidak bisa menentukan dengan cepat. Fokus masalah kita sebenarnya adalah bisa memilah apakah penyebab demam tersebut oleh karena infeksi bakteri atau bukan. Pemilahan secara klinis memang sering tidak selalu bisa menentukan penyebab dengan cepat, pemeriksaan biakan memerlukan waktu yang cukup lama sebelum kita menentukan sikap untuk memberikan antibiotik atau tidak.

Beberapa pemeriksaan penunjang sederhana dapat digunakan sebagai penyaring apakah demam itu disebabkan oleh bakteri atau bukan. Beberapa pemeriksaan penunjang yang bisa diperoleh dengan waktu relatif cepat antara lain $\mathrm{CRP}$ (C reactive protein), ANC (absolute neutrophil count), total leukosit, procalcitonin. Beberapa penelitian sebelumnya telah dilakukan untuk mencoba mencari marker yang dapat menilai apakah demam tersebut disebabkan oleh bakteri atau non bakteri. Salah satu marker tersebut adalah procalcitonin, namun pemeriksaannya memerlukan biaya relatif tinggi sehingga mungkin tidak di semua tempat dapat dilakukan. Pemeriksaan sederhana yang relatif tersedia di setiap tempat pelayanan kesehatan adalah pemeriksaan darah perifer lengkap, hitung jenis dan CRP.

$C$ Reactive Protein merupakan protein fase akut yang dibentuk di hati (oleh sel hepatosit) akibat adanya proses peradangan atau infeksi. ${ }^{2}$ Setelah terjadi peradangan, pembentukan CRP akan meningkat dalam 4 sampai 6 jam, jumlahnya bahkan berlipat dua dalam 8 jam setelah peradangan. Konsentrasi puncak akan tercapai dalam 36 jam sampai 50 jam setelah inflamasi. Kadar CRP akan terus meningkat seiring dengan proses inflamasi yang akan mengakibatkan kerusakan jaringan. Apabila terjadi penyembuhan akan terjadi penurunan kadar CRP secara cepat oleh karena CRP memiliki masa paruh 4 sampai 7 jam. ${ }^{2,3}$ Kinetik metabolism CRP sejalan dengan derajat peradangan dan derajat penyembuhan yang terjadi. Oleh karena itu CRP sangat baik untuk menilai aktivitas penyakit dalam keadaan akut. Pemeriksaan ini relatif tidak mahal dan dapat diperoleh hasilnya dalam waktu cepat serta tidak memerlukan volume darah yang banyak. ${ }^{2-4}$

Trauma atau infeksi pada jaringan mengakibatkan terjadi serangkaian reaksi dengan tujuan untuk mencegah kerusakan jaringan lebih lanjut dan mengaktifkan proses perbaikan. Rangkaian proses tersebut disebut proses inflamasi dan reaksi yang mengawali adalah suatu respon fase akut (acute phase response). . $^{3,4}$

Sel yang mengawali proses inflamasi pada umumnya adalah sel makrofag dan sel monosit. Sel tersebut melepaskan sitokin seperti IL1 dan TNF yang akan mengontrol migrasi leukosit masuk ke dalam jaringan dan menimbulkan proses inflamasi, sehingga terjadi demam dan leukositosis. Inflamasi tersebut juga akan mempengaruhi aktivitas hati. ${ }^{3,5}$ Sitokin pro inflamasi seperti IL1 dan TNF merangsang sel hepatosit untuk meningkatkan produksi protein fase akut seperti CRP dan serum protein amiloid A. Protein tersebut merefleksikan proses inflamasi sehingga terjadi peningkatan sampai 1000 kali dari kadar normal. ${ }^{3-5}$

Neutrofil adalah sel granulosit yang efektif dalam mempertahankan tubuh terutama terhadap infeksi bakteri. ${ }^{6,7}$ Nilai total neutrofil selanjutnya disebut ANC adalah jumlah neutrofil imatur dan neutrofil matur yang beredar di dalam darah tepi. Jumlah ANC umumnya meningkat bila terdapat infeksi bakteri. ${ }^{7,8}$ Nilai ANC dapat dihitung dari hasil hitung jenis dengan menjumlahkan prosentase dari segmen dan batang kemudian dikalikan dengan jumlah total leukosit.

Penelitian kami bertujuan untuk melihat nilai CRP, jumlah leukosit dan nilai total neutrofil, dan suhu badan sebagai uji diagnostik untuk mendeteksi jumlah anak dengan demam dengan penyebab tidak jelas. 
Dalam penelitian ini akan dianalisis nilai sensitivitas, spesifisitas, nilai duga positif, nilai duga negatif, rasio kemungkinan positif dan rasio kemungkinan negatif dari masing-masing pemeriksaan CRP, leukosit, nilai total neutrofil dan suhu badan dengan hasil biakan sebagai baku emas.

\section{Metode}

Uji diagnostik yang dilakukan di Rumah Sakit Umum Pusat Nasional Cipto Mangunkusumo Jakarta dengan mengambil data secara retrospektif dari catatan medis pasien anak yang dirawat di Bangsal Infeksi Anak. Data diambil dengan melihat register rawat inap pasien anak yang dirawat oleh karena demam dengan penyebab yang tidak diketahui. Dari data register yang diperoleh dilakukan penelusuran status pada rekam medik. Dilakukan pencatatan data status rekam medik yang diperlukan meliputi data dasar penderita dan data laboratorium (CRP, leukosit dan hitung jenis, serta hasil biakan).

Data yang didapat ditabulasi, data laboratorium (CRP, leukosit, dan nilai total neutrofil) dan suhu dicari

Pasien yg dirawat di bangsal anak dengan demam yang

tidak jelas penyebabnya

(FWS = fever without source)

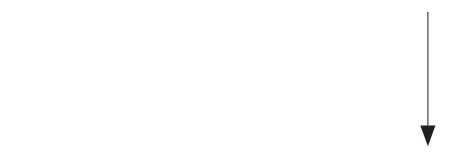

Register ruang anak

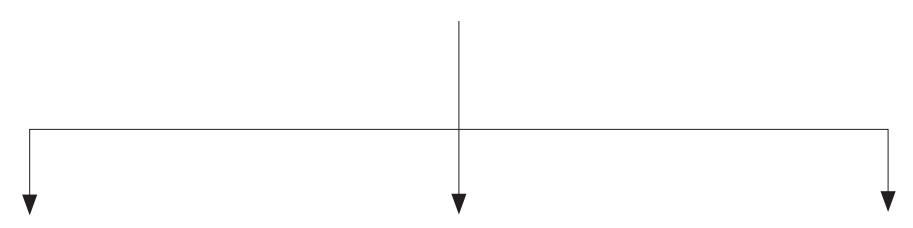

Th 2006

(51 kasus)

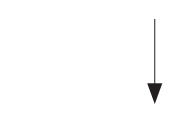

Status yg ditemukan

(32 rekam medik)

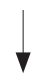

Data lengkap 11

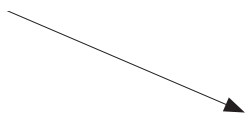

Th 2007

(51 kasus)

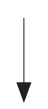

Status yg ditemukan

(41 rekam medik)

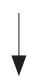

Data lengkap 16

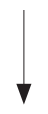

Total subjek

39
Th 2008 (s/d oktober)

(36 kasus)

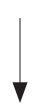

Status yg ditemukan

(25 rekam medik)

Data lengkap 12

Gambar 1. Alur pengumpulan subjek penelitian 
nilai titik potongnya (cut off). Dengan menggunakan standar emas biakan dicari nilai sensitivitas, spesifisitas, nilai duga positif, nilai duga negatif, rasio kemungkinan positif dan rasio kemungkinan negatif baik secara sendiri maupun kombinasi diantara pemeriksaan tersebut. Data diolah dengan menggunakan SPSS 13.0. Untuk mencari nilai sensitivitas, spesifisitas, nilai duga positif, nilai duga negatif, rasio kemungkinan positif dan rasio kemungkinan negatif serta untuk menentukan interval kepercayaan digunakan Vassar Stats dan Catmaker

\section{Hasil}

Menurut penelusuran register selama tiga tahun (tahun 2006 sampai dengan Oktober 2008) didapatkan 138 kasus anak yang dirawat di Bangsal Anak dengan demam leukosit dan ANC dicari nilai titik potongnya (cut off) dengan menggunakan kurve ROC (seperti tampak dalam gambar 2, 3, 4, dan 5).

Berdasarkan masing-masing nilai titik potong yang didapat dibuat tabel $2 \times 2$ selanjutnya dicari nilai sensitivitas, spesifisitas, nilai duga positif, nilai duga negatif, rasio kemungkinan positif, dan rasio kemungkinan negatif dengan masing-masing interval kepercayaannya dengan bantuan Vassar Stats dan Catmaker. Masing-masing nilai cut off CRP, leukosit, ANC dan suhu dicari sensitivitas, spesifisitas, nilai duga positif, nilai duga negatif, rasio kemungkinan positif dan rasio kemungkinan negatif dari CRP, suhu, leukosit dan ANC secara tersendiri, dan disimpulkan seperti tertera pada Tabel 3.

Peneliti juga melakukan penghitungan terhadap nilai ini secara kombinasi antara CRP dan suhu,

Tabel 1. Karakteristik subjek penelitian

\begin{tabular}{|c|c|c|c|}
\hline Karakteristik & $\begin{array}{l}\text { Biakan positif } \\
\quad(\mathrm{n}=26)\end{array}$ & $\begin{array}{l}\text { Biakan negatif } \\
\quad(\mathrm{n}=13)\end{array}$ & $\begin{array}{c}\text { IK 95\% } \\
\text { (biakan positif) }\end{array}$ \\
\hline Umur (median/min-maks) & 2 th (3 bl-12 th) & 2,5 th(2 bl-13 th) & $2,0-4,9$ \\
\hline \multicolumn{4}{|l|}{ Jenis kelamin } \\
\hline Laki (n/\%) & $11(28,2)$ & $8(20,5)$ & \\
\hline Perempuan $(\mathrm{n} / \%)$ & $15(38,5)$ & $5(12,8)$ & \\
\hline Lama demam hari (median/min-maks) & $14(5-60)$ & $14(3-60)$ & $11,9-21,2$ \\
\hline Suhu ${ }^{\circ} \mathrm{C}($ rerata/SD $)$ & $38,8(0,7)$ & $38,4(0,6)$ & $38,5-39,0$ \\
\hline CRP mg/L (median/min-maks) & $48(0-112)$ & $24(0-96)$ & $33,39-65,64$ \\
\hline Leukosit $\mathrm{L} / \mu \mathrm{L}$ (median/min-maks) & $8700(2800-28400)$ & $1140(1200-27800)$ & $8269-13754$ \\
\hline ANC L/ $\mu \mathrm{L}$ (median/min-maks) & $4846(160-17160)$ & $5994(480-13000)$ & $4284-7959$ \\
\hline
\end{tabular}

yang tidak diketahui penyebabnya. Di antara 138 kasus ditemukan 98 rekam medik dan 39 memiliki data yang lengkap sesuai dengan tujuan penelitian. Penelusuran rekam medik tertera pada diagram Gambar 1.

Diantara 39 subjek tersebut dilakukan tabulasi data yaitu umur, jenis kelamin, lama demam sebelum masuk rumah sakit, suhu saat masuk rumah sakit dan data laboratorium saat masuk rumah sakit seperti nilai CRP, leukosit, hitung jenis juga hasil biakan serta diagnosis saat pulang. Data tersebut sebaran distribusinya (normalisasi) kemudian dicari nilai rerata, median, simpang baku, nilai minimum maksimum serta interval kepercayaan. Data ditampilkan dalam tabel data dasar seperti tertera pada Tabel 1 dan 2 .

Data CRP, suhu badan saat masuk rumah sakit,
Tabel 2. Diagnosis skor pulang dari rumah sakit

\begin{tabular}{lc}
\hline Diagnosis & $\mathrm{n}(\%)$ \\
\hline Bakterimia & $5(6,4)$ \\
ISK & $10(12,7)$ \\
Sepsis & $6(7,6)$ \\
Pneumonia & $1(1,3)$ \\
HIV & $2(2,6)$ \\
Ensefalitis & $1(1,3)$ \\
PNA & $2(2,6)$ \\
Tifoid & $1(1,3)$ \\
FUO & $10(12,7)$ \\
\hline
\end{tabular}

$\mathrm{CRP}=C$ Reactive Protein, $\mathrm{ANC}=$ Absolute Neutrophil Count $($ Nilai Total Neutrofil), ISK =Infeksi Saluran Kemih, HIV =Human Immunodeficiency Virus, $\mathrm{PNA}=$ Pielonefritis Acute, $\mathrm{FUO}=$ Fever of Unknown Origin, IK 95\% $=$ Interval Kepercayaan 95\% 


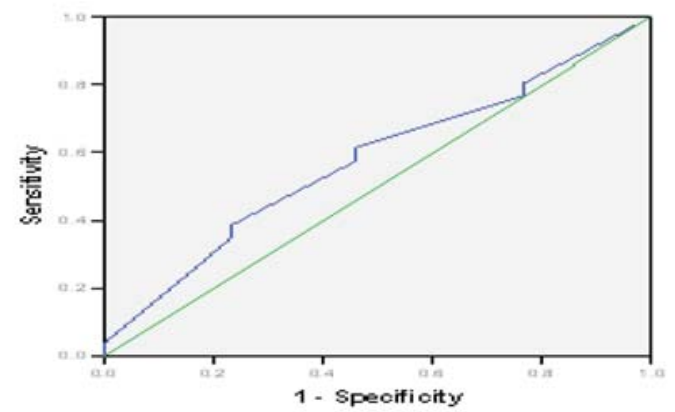

Gambar 2. Kurva ROC dari CRP

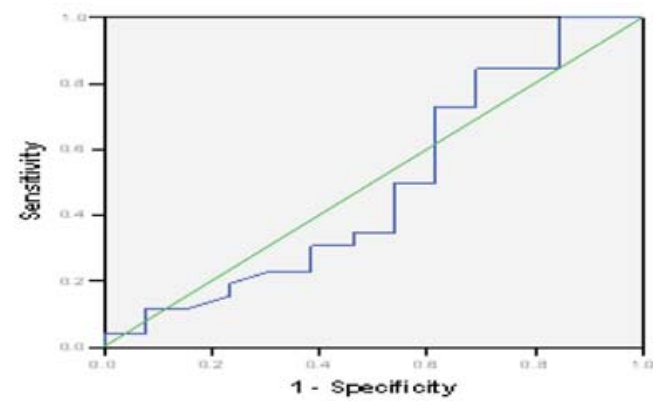

Gambar 4. Kurva ROC dari Leukosit

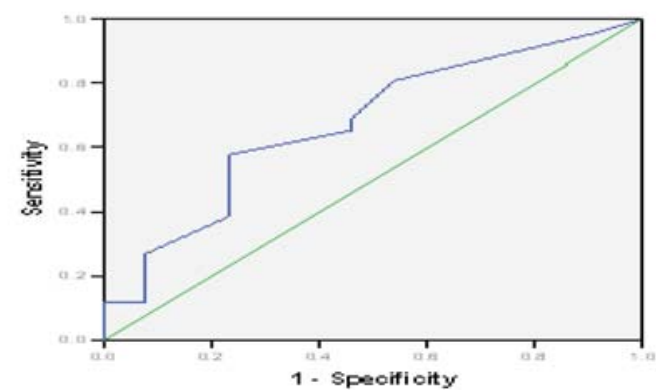

Gambar 3. Kurva ROC dari suhu

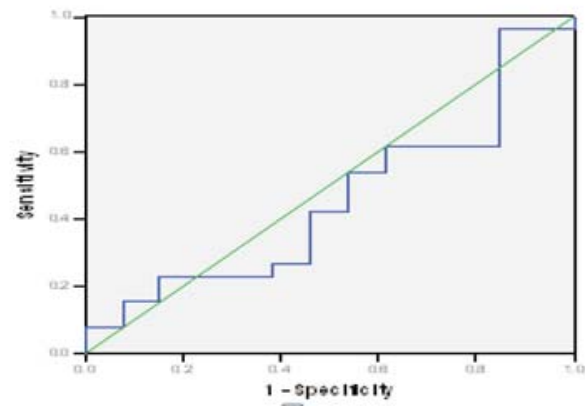

Gambar 5. Kurva ROC dari ANC

Tabel 3. Nilai sensitivitas, spesifisitas, nilai duga positif, nilai duga negatif, dan rasio kemungkinan pemeriksaan CRP, suhu, leukosit dan ANC pada nilai cut off masing-masing

\begin{tabular}{lcccccc}
\hline Pemeriksaan & $\begin{array}{c}\text { Sens } \\
(\mathrm{IK} 95 \%)\end{array}$ & $\begin{array}{c}\text { Spes } \\
(\mathrm{IK} 95 \%)\end{array}$ & $\begin{array}{c}\mathrm{ND}+) \\
(\mathrm{IK} 95 \%)\end{array}$ & $\begin{array}{c}\mathrm{ND}- \\
(\mathrm{IK} 95 \%)\end{array}$ & $\begin{array}{c}\text { RK }+ \\
(\mathrm{IK} 95 \%)\end{array}$ & $\begin{array}{c}\text { RK - } \\
(\mathrm{IK} 95 \%)\end{array}$ \\
\hline CRP & 61,5 & 53,8 & 72 & 41,1 & 1,3 & 0,7 \\
& $(0,40-0.79)$ & $(0,26-0,80)$ & $(0,50-0,88)$ & $(0,19-0,67)$ & $(0,69-2,58)$ & $(0,39-1,32)$ \\
Suhu & 65,4 & 53,8 & 73,9 & 43,7 & 1,4 & 0,6 \\
& $(0,44-0,82)$ & $(0,26-0,80)$ & $(0,51-0,89)$ & $(0,21-0,70)$ & $(0,74-2,71)$ & $(0,33-1,24)$ \\
Leukosit & 42,3 & 46,2 & 61,1 & 28,6 & 0,7 & 1,2 \\
\multirow{2}{*}{ ANC } & $(0,24-0,63)$ & $(0,20-0,74)$ & $(0,36-0,82)$ & $(0,12-0,52)$ & $(0,40-1,54)$ & $(0,75-2,07)$ \\
& 57,7 & 46,1 & 68,2 & 35,5 & 1,1 & 0,9 \\
& $(0,37-0,0,76)$ & $(0,20-0,74)$ & $(0,45-0,85)$ & $(0,15-0,61)$ & $(0,58-1,95)$ & $(0,49-1,71)$ \\
\hline
\end{tabular}

Sens =sensitivitas, Spes=spesifisitas,ND+ = nilai duga + , ND- = nilai duga - , RK+ =rasio kemungkinan + , RK=rasio kemungkinan -, IK 95\%= interval kepercayaan 95\%, CRP= C reaktif protein, $\mathrm{ANC}=$ absolute neutrofil count (hitung neutrofil total)

antara CRP, suhu dan leukosit dan antara CRP, suhu, leukosit, dan ANC secara bersamaan dengan menggunakan biakan sebagai baku emas tertera pada Tabel 4.

\section{Pembahasan}

Penelusuran register rawat inap di Bagian Infeksi Anak didapatkan data anak yang dirawat dengan demam 
I Made Gede Dwi Lingga Utama: Uji diagnostik CRP, leukosit, nilai total neutrofil, dan suhu pada anak demam

Tabel 4. Nilai sensitivitas, spesifisitas, nilai duga positif, nilai duga negatif, dan rasio kemungkinan pemeriksaan kombinasi pada nilai cut off masing-masing

\begin{tabular}{lcccccc}
\hline Pemeriksaan kombinasi & $\begin{array}{c}\text { Sens } \\
\text { (IK 95\%) }\end{array}$ & $\begin{array}{c}\text { Spes } \\
\text { (IK 95\%) }\end{array}$ & $\begin{array}{c}\text { ND + } \\
\text { (IK 95\%) }\end{array}$ & $\begin{array}{c}\text { ND - } \\
(\mathrm{IK} \mathrm{95 \% )}\end{array}$ & $\begin{array}{c}\text { RK + } \\
\text { (IK 95\%) }\end{array}$ & $\begin{array}{c}\text { RK - } \\
\text { (IK 95\%) }\end{array}$ \\
\hline CRP dan leukosit & 15,4 & 69,2 & 50 & 29 & 0,5 & 1,2 \\
CRP, leukosit, dan ANC & $(0,05-0,36)$ & $(0,39-0,90)$ & $(0,17-0,82)$ & $(0,15-0,48)$ & $(0,15-1,69)$ & $(0,97-1,54)$ \\
CRP, leukosit, ANC, dan suhu & 15,4 & 69,2 & 50 & 29,0 & 0,5 & 1,2 \\
& $(0,05-0,36)$ & $(0,39-0,90)$ & $(0,17-0,83)$ & $(0,15-0,48)$ & $(0,15-1,69)$ & $(0,97-1,54)$ \\
& 15,4 & 84,6 & 66,7 & 33,3 & 1 & 1 \\
& $(0,05-0,36)$ & $(0,54-0,97)$ & $(0,24-0,94)$ & $(0,19-0,52)$ & $(0,21-4,77)$ & $(0,83-1,21)$ \\
\hline
\end{tabular}

Sens $=$ sensitivitas, Spes $=$ spesifisitas, $\mathrm{ND}+=$ nilai duga,$+ \mathrm{ND}-=$ nilai duga,$- \mathrm{RK}+=$ rasio kemungkinan,$+ \mathrm{RK}-=$ rasio kemungkinan -, IK 95\%= interval kepercayaan 95\%, CRP= C reaktif protein, $\mathrm{ANC}=$ absolute neutrofil count (hitung neutrofil total)

penyebab yang tidak diketahui selama 3 tahun (tahun 2006, 2007 dan 2008 sampai bulan Oktober). Dari data tersebut tampak kelengkapan data dari tahun ketahun sudah semakin baik yaitu $(21,6 \%)$. Penelitian kami dapat dipakai sebagai penelitian awal untuk kemudian dibuat penelitian dengan tujuan dan langkah yang sama dengan jumlah subjek yang memadai.

Biakan positif 26 kasus dengan prevalensi $66,6 \%$. Secara umum rata-rata umur subjek 3,5 tahun (CI 95\% : 2,3-4,6), umur terkecil 2 bulan dan umur tertua 13 tahun. Titik tengah umur pada biakan positif didapatkan 2 tahun dengan rentang umur antara 3 bulan sampai 12 tahun. Pada biakan positif didapatkan lama demam sekitar 14 hari dengan rentang waktu antara 5 hari sampai 2 bulan. Rerata suhu didapatkan $38,8^{\circ} \mathrm{C}$, nilai tengah $\mathrm{CRP}$, leukosit, dan ANC berturut-turut $48 \mathrm{mg} / \mathrm{L}, 8700 / \mu \mathrm{L}$ dan 4846 $/ \mu \mathrm{L}$. Subjek memiliki sebaran data dengan distribusi yang tidak normal (uji Saphiro Wilk) kecuali sebaran data suhu. Hal tersebut kemungkinan disebabkan oleh jumlah subjek terlalu sedikit.

Diagnosis pulang dari biakan positif terbanyak adalah ISK (infeksi saluran kemih) 10(12,7\%), sepsis 6(7,6\%), dan bakteremia 5(6,4\%). Sensitivitas dari hasil pemeriksaan CRP, leukosit, ANC, dan suhu berkisar antara 42\% sampai dengan 65\%. Begitu juga spesifisitas dari ke empat pemeriksaan tersebut secara tersendiri tidak menunjukkan hasil yang tinggi, berkisar antara $46 \%$ sampai $54 \%$. Hal tersebut menunjukkan pemeriksaan ini belum dapat dipakai sebagai alat untuk skrining maupun diagnosis terhadap pasien anak dengan demam yang tidak diketahui penyebabnya. Bila ditelaah nilai duga negatif berkisar antara $27 \%$ sampai dengan $44 \%$. Hasil tersebut juga belum memberikan hasil yang baik sebagai alat diagnosis untuk menyingkirkan bahwa anak tersebut tidak ada infeksi bakterial.

Hasil pemeriksaan CRP yang didapat dari rekam medik pada penelitian ini adalah hasil pemeriksaan pertama kali saat pasien masuk rumah sakit. Data pemeriksaan serial sulit didapatkan dalam catatan medik. Hal tersebut dapat berpengaruh terhadap hasil karena nilai CRP tersebut memiliki pola tertentu setelah onset infeksi akut. Pada umumnya CRP akan meningkat setelah 12 sampai 24 jam dan memiliki masa paruh 4 sampai 7 jam. ${ }^{2,3}$ Hasil CRP yang didapatkan dari penelitian Caldas $\mathrm{dkk}^{9}$ nilai sensitivitas dan spesifisitas meningkat dengan pengambilan serial terutama pada pengambilan pada 24 jam dari onset penyakit. Szar ${ }^{10}$ mendapatkan nilai diagnostik yang lebih baik bila dilakukan pada jam ke 24 .

Povoa $\mathrm{dkk}^{11}$ menemukan nilai sensitivitas dan spesifisitas CRP pada pasien kritis $(\mathrm{n}=112)$ 93,4 \% dan 86,1 \%. Juga apabila CRP dikombinasikan dengan suhu akan meningkatkan spesifisitas diagnosis. ${ }^{11}$ Pemeriksaan secara kombinasi memberikan nilai sensitivitas yang sangat rendah $15,4 \%$. Hal tersebut dapat dipahami bahwa dengan menggabungkan hasil pemeriksaan tentunya akan meningkatkan spesifisitasnya sehingga tujuan sebagai skreening akan menurun. Hasil spesifisitas secara kombinasi berkisar antara $70 \%$ sampai $85 \%$.

Penggabungan ke empat hasil pemeriksaan tersebut hanya menunjukkan nilai yang tinggi terhadap spesifisitas saja. Rasio kemungkinan positif gabungan ke empat pemeriksaan ini sama dengan rasio 
kemungkinan negatif yaitu 1 . Hal tersebut berarti pemeriksaan ini jauh dari harapan nilai yang baik apabila rasio kemungkinan positif jauh lebih besar dari 1 dan rasio kemungkinan negatif yang baik hendaknya mendekati nilai nol.

Patut disadari bahwa peningkatan leukosit (leukositosis) tidak selalu disebabkan oleh karena adanya infeksi bakteri. Leukositosis secara primer bisa disebabkan oleh gangguan pada bone marrow seperti leukemia atau limfoma, secara sekunder baru disebabkan oleh kondisi abnormal sumsum tulang seperti adanya infeksi bakteri yang sering disebut dengan istilah reaktif leukositosis. Peningkatan leukosit mungkin disebabkan oleh peningkatan neutrofil atau oleh peningkatan eosinofil. ${ }^{10}$ Beberapa penyebab leukositosis adalah neutrofilia (infeksi akut, inflamasi dan nekrosis jaringan), monositosis (infeksi kronik, gangguan inflamasi), eosinofilia (alergi, parasit), basofilia (cacar air), limfositosis (infeksi akut oleh mononukleosis, infeksi kronik misalnya tuberkulosis). ${ }^{10}$ Isaacman $\mathrm{dkk}^{12}$ mendapatkan nilai cut off $\mathrm{ANC}$ $10.600 / \mu \mathrm{L}$ dan menemukan ANC sebagai prediktor yang baik untuk infeksi bakteri yang tersembunyi pada pasien anak $(\mathrm{OBI}=$ occult bacterial infection $)$. Dengan penambahan pemeriksaan CRP tidak memberikan nilai diagnosis yang meningkat.

Al Gwaiz dkk ${ }^{13}$ juga mendapatkan nilai ANC yang lebih baik bila dibandingkan dengan nilai batang pada hitung jenis dimana dapat lebih sensitif dalam memprediksi adanya infeksi bakteri. Akan tetapi dia menemukan nilai batang (band) lebih sensitif pada bayi.

\section{Kesimpulan}

Disimpulkan bahwa nilai CRP, leukosit, ANC dan suhu tidak dapat memberikan prediksi yang baik sebagai prediktor adanya infeksi bakteri pada pasien demam yang tidak jelas penyebabnya. Beberapa kemungkinan sebagai penyebab hasil ini adalah jumlah sampel yang terlalu kecil, kriteria eksklusi yang diterapkan belum bisa menyisihkan penyebab lain dari peningkatan CRP seperi adanya sebab inflamasi lain di luar infeksi bakteri. Demikian juga terhadap lama demam sampel rata-rata 14 hari akan mempengaruhi pola CRP sehingga akan mempengaruhi hasil. Semua hal tersebut diatas sekaligus merupakan kelemahan dalam penelitian ini. Untuk lebih mendapatkan hasil yang mewakili hendaknya dilakukan penelitian ulang dengan jumlah sampel yang lebih banyak sesuai dengan prevalensi kasus. Kriteria eksklusi sampel dipertimbangkan terhadap adanya penyebab inflamasi lain dan keganasan. Hendaknya dilakukan pemeriksaan serial terhadap kadar CRP sesuai dengan masa paruhnya.

\section{Daftar pustaka}

1. Soedarmo SS, Garna H, Hadinegoro SR, Satari HI, penyunting. Buku ajar infeksi dan pediatri tropis. Edisi kedua. Jakarta: Ikatan Dokter Anak Indonesia; 2008. h. 47-55.

2. Carlan P. CRp vs ESR Assessing $\&$ measuring the inflammatory response. Diunduh dari http://www.bpac. org.nz pada tanggal 25 November 2008.

3. Suhendro, Pohan HT. Manfaat Pemeriksaan CRP pada infeksi bakteri akut. Dalam: Widodo D, Pohan HT, editor. Bunga Rampai Penyakit Infeksi. Jakarta: Pusat Informasi dan Penerbitan Departemen Ilmu Penyakit Dalam FK UI, 2004. h.18-29.

4. Jaye, David L, Waites, Ken B. Clinical applications of C-reactive protein in pediatrics. Pediatr Infect Dis J 1997; 16:735-47.

5. C-reactive protein. Diunduh dari http://labtestsonline. org/understanding/analytes/crp/faq.html pada tanggal 10 November 2008.

6. Widman FK. Tinjauan klinis atas hasil pemeriksaan laboratorium. Edisi 9. Jakarta: Penerbit buku kedokteran EGC; 1995. h 91-3.

7. Howard MR, Hamilton PJ. Haematology an illustrated colour text. Third Edition. Edinburg: Churchill Livingstone Elsevier; 2008. h. 6-7.

8. Levy EM. Cell of immune system. In: Pier GB, Lyczak JB, Wetzler LM. Immunology, Infection and Immunity. Washington DC: ASM Press; 2004. h. 53-5.

9. Caldas JP, Sérgio T. M, Maria H. S. L.B, Roseli Calil, Sirlei S. M, dkk. Accuracy of white blood cell count, C-reactive protein, interleukin-6 and tumor necrosis factor alpha for diagnosing late neonatal sepsis. J Pediatr (Rio J) 2008;84:536-42.

10. Szar DH, Walker RA. Crash course pathology. Edisi ke-3. Edinburgh: Mosby Elsevier; 2007. h. 284-6.

11. Pavoa P, Coelho L, Almeida E, Fernandes A, Maelha R, Moriera P, dkk. C-reactive protein as a marker of infection in critically ill patients. Clin Micro Infec 2005; 11:101-8.

12. Isaacman DJ, Burke BL. Utility of serum $C$ reactive 
I Made Gede Dwi Lingga Utama: Uji diagnostik CRP, leukosit, nilai total neutrofil, dan suhu pada anak demam

protein for detection of occult bacterial infection in children. Arch Pediatr Adolesc Med 2002; 156: 905-9.

13. AL Gwaiz LA, Babay HH. The diagnostic value of absolute neutrophil count, band count and morphologic changes of neutrophil in predicting bacterial infections. Med Princ Pract 2007;16:344-7. 